\title{
Physicochemical and Sensory Properties of Restructured Jerky with Four Additives
}

\author{
Su Kyung Ku, Jong Dae Park, Nam Hyuck Lee, Hee Ju Kim¹, and Young Boong Kim* \\ Korea Food Research Institute, Sungnam 463-746, Korea \\ ${ }^{1}$ Meat Bank, Incheon 404-300, Korea
}

\begin{abstract}
This study was carried out to evaluate the effect on properties of restructured jerky by the addition volume of additives. The treatments were divided into glutinous rice flour, potato starch, soybean and acorn powder. Moisture content, water activity $\left(\mathrm{a}_{\mathrm{w}}\right)$, thiobarbituric acid reactive substances (TBARS), color, yield and sensory evaluation were performed. The moisture contents of four types of restructured jerkies were in the range of $8.92-12.47 \%$, and were lower than that of the control (17.92\%). Water activity tended to decreased with increasing addition of all treatments. The restructured jerkies containing glutinous rice flour, potato starch, soybean and acorn powder had lower TBARS than the control. The drying yield tended to increase with increasing amount of additives. In the sensory evaluation results, the highest overall acceptability was found in jerky containing glutinous rice flour, potato starch, and acorn powder when the addition was $9 \%$, while that for soybean powder was determined to be $5 \%$. These results suggest that $9 \%$ additions of glutinous rice flour, potato starch or acorn, or $5 \%$ soybean powder are optimal addition volumes for the preparation of restructured jerkies.
\end{abstract}

Key words: restructured jerky, excipient, water activity, TBARS, property

\section{Introduction}

Consumers prefer to high quality, variety, and convenience food, dine-out accounts for a huge part of the food consumption in Korea these days (Park et al., 2005). In case of meat consumption especially, even though the consumption of fresh meat is most common based upon the 'grilling' cultural background, the demand of healthy meat products such as low fat and functional meat products tends to be increased, recently. In beef, sirloin, tenderloin, and striploin with high fat content are favored while the low fat parts of beef such as shank, rump, and round are not much preferred (Lee and Jin, 2004). Given the fact, there has been an issue regarding unbalance in the beef consumption. In addition to the unbalanced consumption, the beef trimming meat that is produced processing for meat cuts are partially utilized in the production of hamburgers, Tteokgalbi (beef pan cakes), as well as sausages whereas have not been applied for the higher-value added meat products yet.

\footnotetext{
*Corresponding author: Young Boong Kim, Processing Techonology Research Group, Convergence Technology Research Division, Korea Food Research Institute, Sungnam 463-746, Korea. Tel: 82-31-780-9180, Fax: 82-31-780-9076, E-mail: kybaaa@kfri.re.kr
}

Fats have considerable effects on the binding, rheological, structural and sensory properties including flavor, taste, juiciness, and texture of meat products (Hughes et al., 1997; Pearson and Gillett, 1999). Excessive fat intake may cause multiple health problems due to the elevation of cholesterol in body, many consumers demand healthier meat products that are low in fat, cholesterol, nitrites and calories in general. However, reduction of fat in finely ground meat products is extremely challenging and poses difficulties in terms of appearance, flavor, and texture ( $\mathrm{Li}$ and Yeh, 2003). In order to achieve a desirable texture, various texture modifying ingredients and binders are used such as starch, dietary fibers and polydextrose (Skrede, 1989; Trout et al., 1992). Starch is an important biopolymer in food and has been used as a fat replacer in meat products. Starch has been recognized as a filler in surimi and used to increase the firmness of products and enhance the gel strength (Kim and Lee, 1987; VerrezBagnis et al., 1993; Wu et al., 1985). Lots of studies have performed to reduce fat content in meat products and fat replacements that possess the similar physicochemical properties with fat, safflower seed addition (Park et al., 2012), potato powder addition (Ali et al., 2011), and hazelnut or olive oil in fermented sausages (Kayaardi and Gok, 2004; Yildiz-Turp and Serdaroglu, 2008). 
In general, refrigerating, freezing, heating, salting, drying, and smoking process are employed in order to increase the storage of meat and meat products. Among those storage methods, drying lowers water activity $\left(\mathrm{a}_{\mathrm{w}}\right)$ by controlling the moisture content and relative humidity of meat thereby inhibiting the growth of microorganisms. Different microorganisms would grow since water activity varies depending on the products. For instance, snacks have been widely consumed due to the secure of food safety based upon their low water activity (less than 0.70) (Calicioglu et al., 2003). Beef jerky is the most common dried meat product, which is high protein and low fat is produced by seasoning and drying (Lee and Park, 2004). Beef, lamb, pork, and venison are mainly used to produce dried meat (Carr et al., 1997; Choi and An, 1996; Munoz et al., 2012; Lee and Kang, 2001; Park et al., 2009; Van Laak, 1994). Several studies have been carried out with regards to restructured jerky such as the study regarding relationship between drying conditions and quality (Mgbemere et al., 2011; Oh, 2004), the study of physicochemical and microbiological characteristics (Yang et al., 2009), and the study regarding the effects of water activity (Im, 1992). Whereas there is very little information available on the use of additives as fat replacer for restructured jerky and the resulting of the products in Korea.

Therefore, the objective of this study was to investigate the effects of glutinous rice flour, potato starch, soybean and acorn powder addition on the quality properties of restructured jerky produced by utilizing the trimming meats that were generated during the process.

\section{Materials and Methods}

\section{Materials and experimental treatments}

Trimming meat that was used during process was utilized in the production of restructured jerky. The specification of the trimming meat was standardized based on the

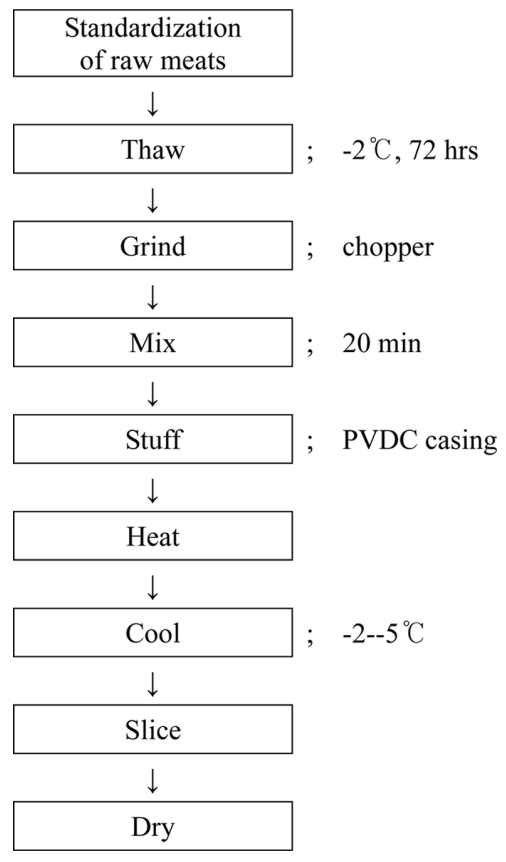

Fig. 1. Basic manufacturing procedure of restructured jerky by amount of glutinous rice flour, potato starch, soybean and acorn powder.

content of general composition (moisture $70.87 \%$, protein $18.42 \%$, fat $10.07 \%$ and ash $0.99 \%$ ). The basic formulation and process was presented in Table 1 and Fig. 1. The trimming meat was ground by a chopper with $5 \mathrm{~mm}$ plate (MEW-727, Mado Co., Germany) and then mixed using a vacuum mixer at 6 bar, $53 \mathrm{rpm}$ (Mixer-600, Hyupjin Co., Korea) for $20 \mathrm{~min}$ following the ratio of formulation. The restructured jerky consisted of the following components (in terms of $\mathrm{w} / \mathrm{w})$ : raw meats $(66.78 \%)$, back fat (19.94\%), additives (glutinous rice flour, potato starch, soybean and acorn powder $(5,9,13$ and 15\%), water $(9.97 \%)$ and others (curing ingredients, salt, frank seasoning, charcoal barbecue taste base, $3.32 \%$ ). The restructured jerky mixture was stuffed into polyvinylidene chloride casing $\Phi 9$ $\mathrm{mm}$ in diameter. After heating at $85^{\circ} \mathrm{C}$ and cooling at -2 to $-5^{\circ} \mathrm{C}$, each preparation was sliced in to $2 \mathrm{~mm}$ widths.

Table 1. Basic formulation of restructured jerky by amount of glutinous rice flour, potato starch, soybean and acorn powder

\begin{tabular}{cccccc}
\hline \hline \multirow{2}{*}{ Ingredients (\%) } & \multicolumn{5}{c}{ Treatments } \\
\cline { 2 - 6 } & Control & 5 & 9 & 66.78 & 13 \\
\hline Raw meats & 66.78 & 66.78 & 10.94 & 6.94 & 66.78 \\
Back fat & 19.94 & 14.94 & 9 & 13 & 4.94 \\
Additives ${ }^{1)}$ & - & 5 & 9.97 & 9.97 & 15 \\
Water & 9.97 & 9.97 & 3.32 & 3.32 & 9.97 \\
Curing inredients etc. & 3.32 & 3.32 & 100 & 100 & 3.32 \\
Total & 100 & 100 & & 100 \\
\hline
\end{tabular}

${ }^{1)}$ Glutinous rice flour (T1), potato starch (T2), soybean (T3) and acorn powder (T4).

${ }^{2)}$ Curing ingredients, salt, frank seasoning, charcoal barbecue taste base. 
Samples were dried in $50^{\circ} \mathrm{C}$ for $7 \mathrm{hr}$. The treatments were divided with glutinous rice flour (T1), potato starch (T2), soybean (T3) and acorn powder (T4) (Table 1).

\section{Moisture content and water activity $\left(a_{w}\right)$}

The moisture content was measured according to method AOAC (1990). Restructured jerky samples were homogenized prior to measurement of water activity $\left(\mathrm{a}_{\mathrm{w}}\right)$. Approximately $2 \mathrm{~g}$ ground samples were put into a holding cup, and then determined by water activity meter (LabMaster-aw CH 8853 Lachen, Novasina, Switzerland).

\section{Thiobarbituric acid reactive substances (TBARS)}

TBARS was measured using the TBA extraction method by Witte et al. (1970). A $10 \mathrm{~g}$ sample was homogenized with $25 \mathrm{~mL}$ trichloroacetic acid (TCA) of $20 \%$ (in $2 \mathrm{M}$ phosphoric acid) and centrifuged at 14,000 rpm for 2 min. Distilled water, $50 \mathrm{~mL}$, was then added to the homogenized sample and stirred for $1 \mathrm{~min}$. After a filtration, 5 $\mathrm{mM}$ TBA was added to $5 \mathrm{~mL}$ of the filtered solution. The mixture was incubated for $15 \mathrm{hrs}$ and then absorbance was measured at $530 \mathrm{~nm}$. TBARS were calculated by the following equation.

TBARS (mg malondialdehyde $(\mathrm{MA}) / \mathrm{kg}$ sample $)=$ Absorbance $\times 5.2$

\section{Color}

Color of samples was measured utilizing a color difference meter (Model CR-300. Minolta Co, Japan) with 9 replicates and expressed as CIE L (Lightness), a (redness), and $b$ (yellowness) with the standard plate of $97.12(\mathrm{~L})$, -0.13 (a), and 2.14 (b).

\section{Drying yield}

Sample weight before and after the drying at $50^{\circ} \mathrm{C}$ for $7 \mathrm{hr}$ was measured and then the drying yield was calculated using the following equation.

Drying yield $(\%)=100-\{($ sample weight before drying (g) - sample weight after drying (g)) / sample weight before drying $(\mathrm{g}) \times 100\}$

\section{Sensory evaluation}

Sensory evaluation of samples is carried out against appearance, flavor, taste, texture acceptability, and overall acceptability with a scale of 9 points by 20 panels. Scores obtained by panels indicates appearance, flavor, and taste $(1=$ extremely bad, $9=$ extremely good), texture (crispi- ness: $1=$ extremely soggy, $9=$ extremely crispy), texture acceptability and overall acceptability $(1=$ dislike extremely, $9=$ like extremely).

\section{Statistical analysis}

Statistical analysis was performed using SAS (Statistical Analysis System, 2002) program and the results were expressed as mean and standard deviation. Significance tests were done using ANOVA and Duncan's multiple range tests $(p<0.05)$ were carried out as post-hoc test.

\section{Results and Discussion}

\section{Moisture content, water activity $\left(a_{w}\right)$ and drying yield}

The moisture content, water activity and drying yield of restructured jerky with amounts of glutinous rice flour (T1), potato starch (T2), soybean (T3) and acorn powder (T4) were showed in Table 2. The moisture content was in the range of $8.92-10.73 \%, 7.90-9.81 \%, 7.18-9.73 \%$, and $11.50-12.47 \%$ with glutinous rice flour, potato starch, soybean, and acorn powder, respectively. The moisture content was decreased by glutinous rice flour and potato starch were added, whereas was increased as soybean powder and acorn powder were added $(p<0.05)$. The moisture content of the control was significantly higher $(17.92 \%)$ compared to those of other treatments $(p<0.05)$ and was similar to the commercially available beef jerky (approximately $20 \%$ of moisture content) produced in Korea (Jung et al., 1994). Among the restructured jerky with soybean powder, 13\% soybean powder added had the lowest moisture content, whereas addition of $5 \%$ in acorn powder was the lowest. The moisture content of additives used in this study was determined and the results showed glutinous rice flour $10.86 \pm 0.32 \%$, potato starch $12.08 \pm 0.31 \%$, soybean powder $0.93 \pm 0.07 \%$, and acorn powder $16.43 \pm 0.36 \%$, respectively. Acorn powder treatment contained the highest moisture content among other treatments. Since the restructured jerky with acorn powder added was also showed the highest moisture content, the moisture content of the additive seemed to influence on the moisture content of the restructured jerky with the additive.

Water activity is the classification standard for dried food. Generally the water activity of semi-dried food should be ranged $0.60-0.90$ so that are considered to be relatively safe food against microorganisms. It was reported that drying temperature, water activity, and addition of preservatives including salt and sugar were af- 
Table 2. Moisture contents, water activity $\left(a_{w}\right)$ and drying yield of restructured jerky by amount of glutinous rice flour, potato starch, soybean and acorn powder

\begin{tabular}{|c|c|c|c|c|c|}
\hline & Treatments (\%) & Glutinous rice flour & Potato starch & Soybean powder & Acorn powder \\
\hline \multirow{5}{*}{$\begin{array}{l}\text { Moisture content } \\
\qquad(\%)\end{array}$} & Control & $17.92 \pm 0.29^{\mathrm{a}}$ & $17.92 \pm 0.29^{\mathrm{a}}$ & $17.92 \pm 0.29^{\mathrm{a}}$ & $17.92 \pm 0.29^{\mathrm{a}}$ \\
\hline & 5 & $10.73 \pm 0.63^{\mathrm{Ab}}$ & $9.81 \pm 1.24^{\mathrm{Ab}}$ & $7.51 \pm 0.04^{\mathrm{Bd}}$ & $11.50 \pm 0.15^{\mathrm{Ac}}$ \\
\hline & 9 & $9.53 \pm 0.11^{\mathrm{Bbc}}$ & $9.29 \pm 0.08^{\mathrm{Bbc}}$ & $7.18 \pm 0.00^{\mathrm{Cd}}$ & $11.74 \pm 0.29^{\mathrm{Abc}}$ \\
\hline & 13 & $9.25 \pm 0.70^{\mathrm{Bbc}}$ & $8.80 \pm 0.25^{\mathrm{Bbc}}$ & $9.73 \pm 0.28^{\mathrm{Bb}}$ & $12.47 \pm 0.21^{\mathrm{Ab}}$ \\
\hline & 15 & $8.92 \pm 0.92^{\mathrm{Bc}}$ & $7.90 \pm 0.09^{\mathrm{Bc}}$ & $8.13 \pm 0.06^{\mathrm{Bc}}$ & $12.08 \pm 0.00^{\mathrm{Ab}}$ \\
\hline \multirow{5}{*}{$\begin{array}{l}\text { Water activity } \\
\qquad\left(\mathrm{a}_{\mathrm{w}}\right)\end{array}$} & Control & $0.76 \pm 0.01^{\mathrm{a}}$ & $0.76 \pm 0.01^{\mathrm{a}}$ & $0.76 \pm 0.01^{\mathrm{a}}$ & $0.76 \pm 0.01^{\mathrm{a}}$ \\
\hline & 5 & $0.62 \pm 0.00^{\mathrm{Bb}}$ & $0.63 \pm 0.01^{\mathrm{Bb}}$ & $0.50 \pm 0.01^{\mathrm{Cd}}$ & $0.66 \pm 0.00^{\mathrm{Ad}}$ \\
\hline & 9 & $0.59 \pm 0.01^{\mathrm{Bc}}$ & $0.55 \pm 0.03^{\mathrm{Bc}}$ & $0.49 \pm 0.00^{\mathrm{Cd}}$ & $0.68 \pm 0.00^{\mathrm{Acd}}$ \\
\hline & 13 & $0.55 \pm 0.00^{\mathrm{Cd}}$ & $0.54 \pm 0.01^{\mathrm{Ccd}}$ & $0.63 \pm 0.00^{\mathrm{Bb}}$ & $0.70 \pm 0.00^{\mathrm{Ab}}$ \\
\hline & 15 & $0.54 \pm 0.00^{\mathrm{BCd}}$ & $0.50 \pm 0.00^{\mathrm{Cd}}$ & $0.58 \pm 0.03^{\mathrm{Bc}}$ & $0.69 \pm 0.00^{\mathrm{Abc}}$ \\
\hline \multirow{5}{*}{$\begin{array}{l}\text { Drying yield } \\
(\%)\end{array}$} & Control & $44.02 \pm 0.06^{\mathrm{c}}$ & $44.02 \pm 0.06^{\mathrm{d}}$ & $44.02 \pm 0.06^{\mathrm{c}}$ & $44.02 \pm 0.06^{b}$ \\
\hline & 5 & $38.54 \pm 0.17^{\mathrm{De}}$ & $43.28 \pm 0.45^{\mathrm{Ae}}$ & $39.56 \pm 0.14^{\mathrm{Cd}}$ & $41.15 \pm 0.08^{\mathrm{Bc}}$ \\
\hline & 9 & $42.11 \pm 0.03^{\mathrm{Dd}}$ & $46.81 \pm 0.08^{\mathrm{Ab}}$ & $43.27 \pm 0.15^{\mathrm{Cc}}$ & $44.97 \pm 0.62^{\mathrm{Bb}}$ \\
\hline & 13 & $46.92 \pm 0.12^{\mathrm{Ba}}$ & $46.14 \pm 0.15^{\mathrm{Cc}}$ & $46.11 \pm 0.16^{\mathrm{Cb}}$ & $48.26 \pm 0.45^{\mathrm{Aa}}$ \\
\hline & 15 & $46.28 \pm 0.09^{\mathrm{Cb}}$ & $52.15 \pm 0.30^{\mathrm{Aa}}$ & $47.42 \pm 0.59^{\mathrm{BCa}}$ & $48.59 \pm 0.55^{\mathrm{Ba}}$ \\
\hline
\end{tabular}

${ }^{\mathrm{A}-\mathrm{D}}$ Means with different superscripts in the same row represent significant difference at $p<0.05$.

${ }^{\mathrm{a}-\mathrm{d}}$ Means with different superscripts in the same column represent significant difference at $p<0.05$.

Table 3. TBARS of restructured jerky by amount of glutinous rice flour, potato starch, soybean and acorn powder

\begin{tabular}{cccccc}
\hline \hline & Treatments (\%) & Glutinous rice flour & Potato starch & Soybean powder & Acorn powder \\
\hline & Control & $0.53 \pm 0.01^{\mathrm{a}}$ & $0.53 \pm 0.01^{\mathrm{a}}$ & $0.53 \pm 0.01^{\mathrm{a}}$ & $0.53 \pm 0.01^{\mathrm{a}}$ \\
TBA & 5 & $0.22 \pm 0.01^{\mathrm{Cc}}$ & $0.14 \pm 0.01^{\mathrm{Dc}}$ & $0.31 \pm 0.01^{\mathrm{Bb}}$ & $0.57 \pm 0.04^{\mathrm{Aa}}$ \\
(mg MA/kg sample) $^{\mathrm{Bb}}$ & 9 & $0.26 \pm 0.01^{\mathrm{Bc}}$ & $0.18 \pm 0.02^{\mathrm{Bc}}$ & $0.42 \pm 0.05^{\mathrm{Aab}}$ & $0.43 \pm 0.04^{\mathrm{Ab}}$ \\
& 13 & $0.38 \pm 0.01^{\mathrm{Cb}}$ & $0.49 \pm 0.02^{\mathrm{Ab}}$ & $0.44 \pm 0.02^{\mathrm{Bab}}$ & $0.37 \pm 0.01^{\mathrm{Cb}}$ \\
& 15 & $0.52 \pm 0.04^{\mathrm{Aa}}$ & $0.47 \pm 0.04^{\mathrm{Ab}}$ & $0.48 \pm 0.11^{\mathrm{Aa}}$ & $0.21 \pm 0.03^{\mathrm{Bc}}$ \\
\hline
\end{tabular}

A-D Means with different superscripts in the same row represent significant difference at $p<0.05$.

${ }^{\mathrm{a}-\mathrm{c}}$ Means with different superscripts in the same column represent significant difference at $p<0.05$.

fected on the storage (Ledward, 1981). Studies also suggested that browning reaction tended to be accelerated at high water activity and microorganisms was easily grown when water activity was greater than 0.85 . Furthermore, it was showed that water activity should be lowered less than 0.7 in order to extention during storage (Banwart, 1979; Im, 1992). In this study, the water activity was ranged of $0.54-0.62,0.50-0.63,0.49-0.63$, and $0.66-0.70$ according to the amount of glutinous rice flour, potato starch, soybean, and acorn powder added, respectively. The water activity showed a decreasing tend to as more glutinous rice flour (T1), potato starch (T2) and soybean powder (T3) were added while was increased as the amount of acorn powder (T4) addition was increased. This would be associated with the increased moisture content when the amount of acorn powder addition was increased. This is similar to the result by Allen et al. (2007) indicating that there was a positive correlation between water activity and moisture content. In addition, Lee and Kang (2001) reported that the water activity of dried ostrich meat was decreased with the decrease of moisture content. Meanwhile, when comparing between the water activity of the samples at the same amount of additives, the water activity with acorn powder was significantly higher compared to other additives like the result of moisture content. When adding 5\% and $9 \%$ of additives, the soybean powder added samples showed the lowest water activity while the low water activity was exhibited in restructured jerky with glutinous rice flour and potato starch for $13 \%$ and $15 \%$ additives, but no significant differences.

In the results of the drying yield, it tended to be increased as the amount of glutinous rice flour, potato starch, soybean, and acorn powder in the samples was increased. The drying yield of the samples added with higher than $13 \%$ of glutinous rice flour (T1) and soybean powder (T3) were relatively higher than that of the control $(44.02 \%)$. All the samples added with potato starch (T2) and acorn power (T4) except for the 5\% showed significantly higher drying yield compared to that of the control $(p<0.05)$. In the comparison of the samples at the same amount of additives, significantly high drying yield was 
showed in the samples added with $5 \%, 9 \%$, and $15 \%$ of potato starch while the sample with $13 \%$ of acorn powder addition tended to result in high.

In general, starch and flour improve cohesiveness as well as water holding capacity in food. Several studies reported that application of such additives in meat products allowed being able to form the gels with enhanced water holding capacity and emulsifying capacity thereby increasing the yield of meat products (Chin et al., 1999; Shewry and Tatham, 2000). This study was also showed that the yield was increased by increasing the amount of glutinous rice flour, potato starch, soybean and acorn powder. Thus given the results, glutinous rice flour, potato starch, soybean, and acorn powder were showed to be the effective additives increase the yield in the production of restructured jerky. Berry (1997) reported that the yield of meat products was increased with the addition of pea fibers and tapioca starch, which was also in similar to this study.

\section{Thiobarbituric acid reactive substances (TBARS)}

In high fat meat products, thiobarbituric acid reactive substances (TBARS), an indicator to predict the degree of lipid oxidation, is measured by determining the amount of malonaldehyde which is produced in the auto-oxidation during storage (Raharjo and Brewer, 2007). Park et al. (2012) reported that dry-cured meat was tend to oxidative rancidity by oxidants while curing. The result of TBARS against restructured jerky which was added the amount of treatments was showed in Table 3. As a result, TBARS in the restructured jerky added with amount of glutinous rice flour (T1), potato starch (T2), soybean (T3) and acorn powder (T4) were ranged of 0.22-0.52, 0.14-0.47, 0.310.48 , and $0.21-0.57 \mathrm{mg} \mathrm{MA} / \mathrm{kg}$ sample, respectively. Increased TBARS was showed in the glutinous rice flour, potato starch, and soybean powder added restructured jerky samples. Compared to the control, TBARS for the potato starch added samples were significantly lower $(p<0.05)$. In this study, significant difference was not showed between the control and the samples added with more than $15 \%$ and $9 \%$ of rice flour (T1) and soybean power (T3), respectively. On the other hand, TBARS in the acorn powder (T4) sample was reduced when the concentration was increased so was different from the samples with the other additives. Comparing to the restructured jerky samples at the same amount of the additives, $5 \%$ of acorn powder addition resulted in significantly higher TBARS than that of the other samples with 5\% additives while TBARS of $15 \%$ acorn powder added sam- ples were significantly low. Moreover, TBARS tended to be low when $\mathrm{T} 1$ and $\mathrm{T} 2$ were added by $5 \%$ and $9 \%$ while TBARS in the $15 \%$ of glutinous rice flour (T1), potato starch (T2) and soybean (T3) added samples was significantly high. This result was in accordance with that of Torres et al. (1994) and Han et al. (2007) who reported that TBARS increased with the decreased of $\mathrm{a}_{\mathrm{w}}$ in dry-cured pork sausage and pork jerky. Whereas in this study, the decreased TBARS by the increase of acorn powder addition was showed to be caused by the antioxidant effects of acorns. Many researchers reported that acorns, which consisted of approximately $70 \%$ of starch, were involved in astriction and contained a lot of tannin (6-9\%), gallic acid, digallic acid, and gallotannin thereby having antioxidant effects (Kwon et al., 2002; Lee et al., 1992; Lopes et al., 1999). Therefore, the result suggested that the addition of glutinous rice flour, potato starch, soybean, and acorn powder could potentially be as fat replacements.

\section{Color}

Color was evaluated for restructured jerky depending on amount of glutinous rice flour (T1), potato starch (T2), soybean (T3) and acorn powder (T4). The results were showed in Fig. 2. Lightness (L) of treatments samples resulted in the ranges of 44.40-51.29 (T1), 47.80-51.50 (T2), 37.58-41.74 (T3), and 34.22-36.38 (T4), respectively. The $\mathrm{L}$ value of samples added with glutinous rice flour and potato starch showed higher than control (38.69). However, restructured jerky with soybean powder samples was significantly different from the $5 \%$ and acorn powder significantly the highest was found in the control $(p<0.05)$. Jin and Ban (2008) reported that tannin was responsible for the darkness of acorn powder. They also reported that significantly low lightness was showed in the acorn added sausages, which was similar to this study. Redness (a) of the samples added with treatments were in the range of 11.41-19.55 (T1), 9.51-17.88 (T2), 6.15-9.09 (T3), and 4.94-9.95 (T4), respectively, indicating significant reduction in the redness with the increase of the amount of addition regarding all additives. The soybean and acorn powder fortified samples showed the highest redness in the control $(p<0.05)$. Yellowness (b) was ranged of 7.62-9.99, 7.18-11.89, 4.32-4.59, and 2.633.22 for glutinous rice flour, potato starch, soybean, and acorn powder added samples, respectively. It was showed that the $b$ value in the glutinous rice flour and potato starch added restructured jerkies tended to be higher compared to that of the control (3.96) while it was relatively lower in the acorn powder samples than that of the con- 

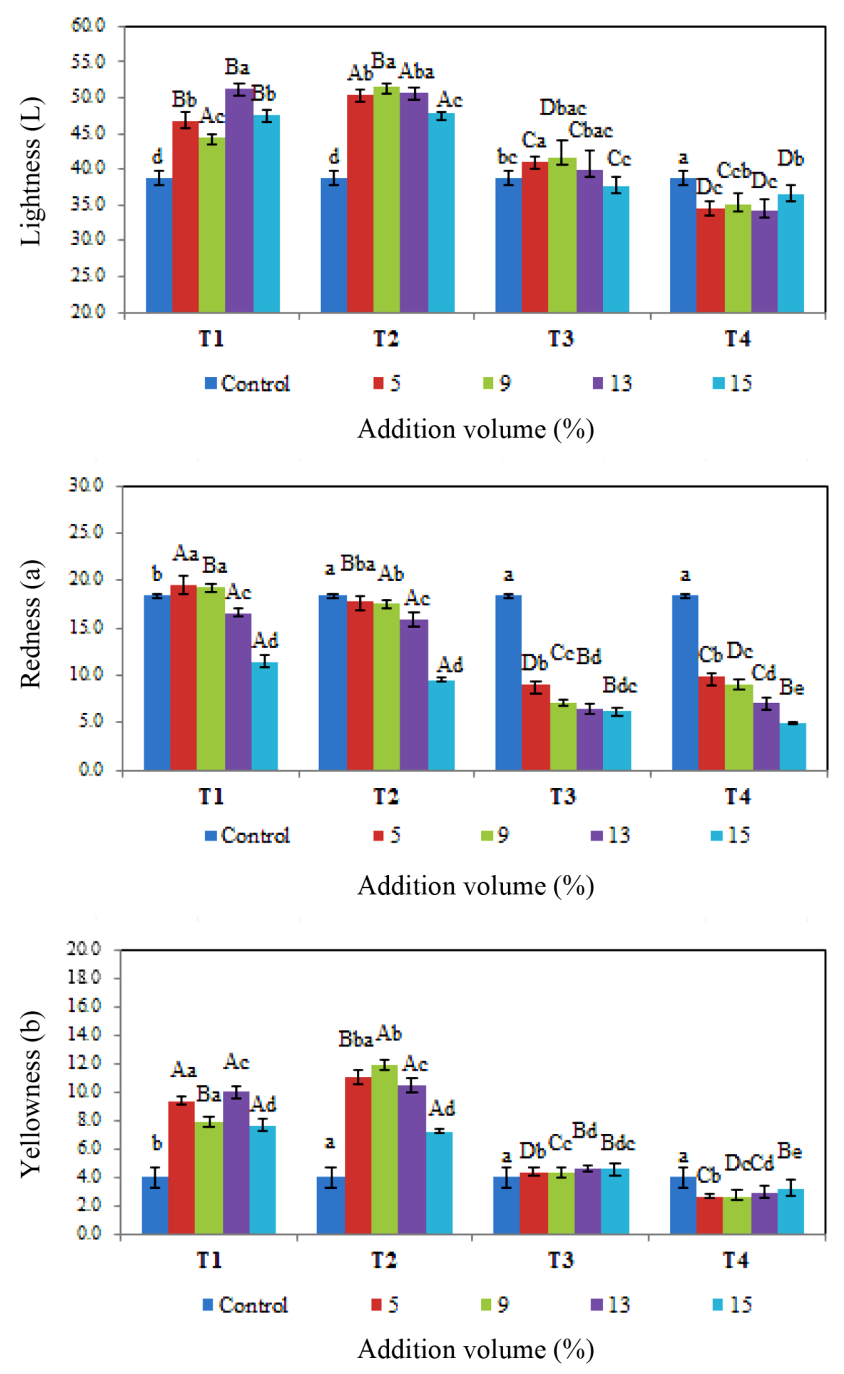

Fig. 2. Color value of restructured jerky by amount of glutinous rice flour (T1), potato starch (T2), soybean (T3) and acorn powder (T4). ${ }^{A-D}$ Different letters indicate significant differences among treatments within the same addition volume $(p<0.05) .{ }^{\mathrm{a}-\mathrm{e}}$ Different letters indicate significant differences among addition volume within the same treatment $(p<0.05)$.

trol $(p<0.05)$. However, in the samples added with soybean powder, it was no significant differences showed between the control and samples added with all kinds of additives. Comparing to the restructured jerkies added with same amount, it was showed that $\mathrm{L}$ value and a value tended to be high in the samples added with $\mathrm{T} 1$ and $\mathrm{T} 2$ whereas low in the T3 and T4 added samples. In contrast, it was reported that $b$ value was low in the samples with soybean and acorn powder. Numerous studies have reported that the color of restructured jerky is typically dependent on light, oxygen, temperature, and process and packaging conditions and the color based upon drying duration is influenced by the moisture content of the products (Acton and Dick, 1977; Cava et al., 2009; Chasco et al., 1996; García-Esteban et al., 2004; Mancini and Hunt, 2005; Rubio et al., 2008).

\section{Sensory evaluation}

Sensory evaluation results of the restructured jerky added with 4 treatments were presented in Table 4 . The samples added with $5 \%$ of glutinous rice flour were scored high in appearance and the score was tended to be decreased as the amount of glutinous rice flour in the samples was increased. Moreover, the $15 \%$ of glutinous rice flour added ones resulted in the lowest overall acceptability. High scores in flavor and taste were showed in the samples at $5 \%$ and $9 \%$ of additives, respectively. Crispiness was increased as greater amount of glutinous rice flour was present in the samples. The highest acceptability was showed in the samples with $9 \%$ additives, but indicating no significant differences compared to that of the other samples. Overall, the restructured jerky added with $9 \%$ additives was showed the highest preference while there was no significant difference compared to that of the ones fortified with $5 \%$ additives. Considering the TBARS and drying yield in the case, the samples with $9 \%$ additives seemed to be more suitable due to relatively lower TBARS and drying yield. Similar to the glutinous rice flour, the samples tended to be crispier when more potato starch was added to the samples. The potato starch samples with $9 \%$ additives resulted in the highest scores in flavor, taste, and texture acceptability, however representing that significant differences were not found compared to the other samples. Based upon the price of potato starch and back fat, when fewer carriers are present in the samples, it might be more economical but result in low yield. Therefore, it would be more suitable to add $9 \%$ of additives which were scored generally high in flavor, taste, and texture acceptability. For the soybean powder added samples, the 5\% added samples showed the highest scores in appearance and the appearance was significantly less liked as the amount of additives was increased except for the $9 \%$ samples. As like lightness was decreased with the addition of soybean powder, visible darkness might be attributed lowering the appearance preference. There were no significant differences showed in favor and taste based upon the kinds of additives. In case of soybean powder, differences in flavor and taste would not be identified up to $15 \%$ samples because of its own strong flavor and taste. With the increase of soybean powder content, the samples tended to be crispier but significant differences were not showed in the acceptability. Unlike res- 
Table 4. Sensory evaluation of restructured jerky by amount of glutinous rice flour, potato starch, soybean and acorn powder

\begin{tabular}{|c|c|c|c|c|c|}
\hline & Treatments (\%) & Glutinous rice flour & Potato starch & Soybean powder & Acorn powder \\
\hline \multirow{5}{*}{ Appearance $^{1)}$} & Control & $6.86 \pm 1.21^{\mathrm{ba}}$ & $6.86 \pm 1.21^{\mathrm{a}}$ & $6.86 \pm 1.21^{\mathrm{a}}$ & $6.86 \pm 1.21^{\mathrm{a}}$ \\
\hline & 5 & $7.33 \pm 0.87^{\mathrm{Aa}}$ & $6.67 \pm 0.87^{\mathrm{ABa}}$ & $7.00 \pm 1.31^{\mathrm{Aa}}$ & $5.88 \pm 1.25^{\mathrm{Bab}}$ \\
\hline & 9 & $7.22 \pm 1.09^{\mathrm{Aa}}$ & $6.56 \pm 0.73^{\mathrm{ABa}}$ & $5.88 \pm 1.13^{\mathrm{BCab}}$ & $5.13 \pm 1.36^{\mathrm{Cbc}}$ \\
\hline & 13 & $6.33 \pm 0.87^{\mathrm{Aab}}$ & $5.44 \pm 0.88^{\mathrm{ABb}}$ & $5.25 \pm 0.71^{\mathrm{BCbc}}$ & $4.38 \pm 1.19^{\mathrm{Cc}}$ \\
\hline & 15 & $5.98 \pm 0.78^{\mathrm{Ab}}$ & $4.89 \pm 1.05^{\mathrm{ABb}}$ & $4.63 \pm 1.19^{\mathrm{Bc}}$ & $4.50 \pm 1.41^{\mathrm{Bbc}}$ \\
\hline \multirow{5}{*}{ Flavor } & Control & $6.57 \pm 1.13^{\mathrm{ba}}$ & $6.57 \pm 1.13$ & $6.57 \pm 1.13$ & $6.57 \pm 1.13$ \\
\hline & 5 & $7.22 \pm 0.67^{\mathrm{Aa}}$ & $7.33 \pm 1.00^{\mathrm{A}}$ & $5.63 \pm 0.92^{\mathrm{B}}$ & $6.00 \pm 0.53^{\mathrm{B}}$ \\
\hline & 9 & $6.78 \pm 0.67^{\mathrm{ABab}}$ & $7.56 \pm 0.73^{\mathrm{A}}$ & $5.88 \pm 0.83^{\mathrm{B}}$ & $6.63 \pm 1.19^{\mathrm{AB}}$ \\
\hline & 13 & $6.67 \pm 0.50^{\text {Aab }}$ & $6.56 \pm 1.13^{\mathrm{AB}}$ & $5.63 \pm 1.06^{\mathrm{B}}$ & $6.13 \pm 0.99^{\mathrm{AB}}$ \\
\hline & 15 & $6.33 \pm 0.87^{\mathrm{Ab}}$ & $6.33 \pm 1.00$ & $5.38 \pm 1.51$ & $4.50 \pm 1.41$ \\
\hline \multirow{5}{*}{ Taste } & Control & $7.00 \pm 1.15^{\mathrm{ba}}$ & $7.00 \pm 1.15^{\text {ab }}$ & $7.00 \pm 1.15^{\mathrm{a}}$ & $7.00 \pm 1.15^{\mathrm{a}}$ \\
\hline & 5 & $6.78 \pm 0.97^{\mathrm{ABab}}$ & $7.78 \pm 0.67^{\mathrm{Aa}}$ & $6.00 \pm 1.31^{\mathrm{Bab}}$ & $6.00 \pm 1.31^{\mathrm{Bab}}$ \\
\hline & 9 & $7.22 \pm 1.09^{\mathrm{Aa}}$ & $7.89 \pm 0.78^{\mathrm{Aa}}$ & $5.75 \pm 1.16^{\mathrm{Bab}}$ & $6.88 \pm 1.13^{\mathrm{Aa}}$ \\
\hline & 13 & $6.33 \pm 0.71^{\mathrm{ABab}}$ & $6.67 \pm 1.32^{\mathrm{Ab}}$ & $5.25 \pm 1.28^{\mathrm{Bb}}$ & $6.00 \pm 1.31^{\mathrm{ABab}}$ \\
\hline & 15 & $6.00 \pm 1.41^{\mathrm{ABb}}$ & $6.11 \pm 1.05^{\mathrm{b}}$ & $5.50 \pm 1.51^{\mathrm{b}}$ & $6.00 \pm 1.31^{\mathrm{b}}$ \\
\hline \multirow{5}{*}{$\begin{array}{l}\text { Texture } \\
\text { (degree) }\end{array}$} & Control & $2.71 \pm 1.25^{\mathrm{c}}$ & $2.71 \pm 1.25^{\mathrm{c}}$ & $2.71 \pm 1.25^{\mathrm{c}}$ & $2.71 \pm 1.25^{\mathrm{c}}$ \\
\hline & 5 & $5.33 \pm 1.58^{\mathrm{BCb}}$ & $5.89 \pm 0.93^{\mathrm{Bb}}$ & $7.63 \pm 1.06^{\mathrm{Aa}}$ & $4.50 \pm 1.51^{\mathrm{Cb}}$ \\
\hline & 9 & $6.00 \pm 1.00^{\mathrm{ABab}}$ & $6.22 \pm 0.83^{\mathrm{ABab}}$ & $7.00 \pm 1.20^{\mathrm{Aab}}$ & $5.13 \pm 1.36^{\mathrm{Bab}}$ \\
\hline & 13 & $6.67 \pm 0.87^{\mathrm{Aa}}$ & $6.78 \pm 1.20^{\mathrm{Aab}}$ & $5.75 \pm 1.28^{\mathrm{ABb}}$ & $5.50 \pm 0.93^{\mathrm{Bab}}$ \\
\hline & 15 & $7.00 \pm 1.41^{\mathrm{ABa}}$ & $7.11 \pm 0.78^{\mathrm{Aa}}$ & $6.25 \pm 1.39^{\mathrm{ABb}}$ & $4.75 \pm 1.16^{\mathrm{Ba}}$ \\
\hline \multirow{5}{*}{$\begin{array}{c}\text { Texture } \\
\text { (acceptability) }\end{array}$} & Control & $4.57 \pm 0.98^{b}$ & $4.57 \pm 0.98^{b}$ & $4.57 \pm 0.98^{b}$ & $4.57 \pm 0.98$ \\
\hline & 5 & $6.00 \pm 1.66^{\mathrm{a}}$ & $6.22 \pm 0.97^{\mathrm{a}}$ & $6.75 \pm 1.28^{\mathrm{a}}$ & $5.38 \pm 1.51$ \\
\hline & 9 & $6.22 \pm 1.30^{\mathrm{a}}$ & $6.22 \pm 0.97^{\mathrm{a}}$ & $6.13 \pm 1.13^{\mathrm{a}}$ & $5.63 \pm 1.19$ \\
\hline & 13 & $5.78 \pm 0.97^{\mathrm{ab}}$ & $6.00 \pm 1.41^{\mathrm{a}}$ & $5.50 \pm 1.51^{\mathrm{ab}}$ & $5.50 \pm 1.41$ \\
\hline & 15 & $6.00 \pm 1.22^{\mathrm{a}}$ & $6.22 \pm 0.97^{\mathrm{a}}$ & $5.38 \pm 1.19^{\mathrm{ab}}$ & $5.88 \pm 0.83$ \\
\hline \multirow{5}{*}{$\begin{array}{c}\text { Overall } \\
\text { Acceptability }\end{array}$} & Control & $5.71 \pm 0.95^{\mathrm{AB}}$ & $5.71 \pm 0.95^{\mathrm{b}}$ & $5.71 \pm 0.95^{\mathrm{ab}}$ & $5.71 \pm 0.95^{\mathrm{ab}}$ \\
\hline & 5 & $6.33 \pm 1.22^{\mathrm{AB}}$ & $7.00 \pm 0.87^{\mathrm{Aa}}$ & $6.50 \pm 1.20^{\mathrm{ABa}}$ & $5.63 \pm 1.19^{\mathrm{Bab}}$ \\
\hline & 9 & $6.56 \pm 1.01$ & $7.11 \pm 1.05^{\mathrm{Aa}}$ & $5.75 \pm 1.16^{\mathrm{Bab}}$ & $6.38 \pm 1.19^{\mathrm{ABa}}$ \\
\hline & 13 & $5.78 \pm 0.97^{\mathrm{A}}$ & $6.44 \pm 0.88^{\mathrm{Aab}}$ & $5.38 \pm 1.60^{\mathrm{Bab}}$ & $6.13 \pm 1.25^{\mathrm{ABab}}$ \\
\hline & 15 & $6.11 \pm 0.93$ & $5.89 \pm 0.78^{\mathrm{ABb}}$ & $4.75 \pm 1.16^{\mathrm{Cb}}$ & $4.88 \pm 1.36^{\mathrm{BCb}}$ \\
\hline
\end{tabular}

${ }^{\mathrm{A}-\mathrm{C}}$ Means with different superscripts in the same row represent significant difference at $p<0.05$.

${ }^{\mathrm{a}-\mathrm{c}}$ Means with different superscripts in the same column represent significant difference at $p<0.05$

${ }^{1)}$ appearance, flavor, and taste $(1=$ extremely bad, $9=$ extremely good), texture (crispiness: $1=$ extremely soggy, $9=$ extremely crispy), texture acceptability and overall acceptability $(1=$ dislike extremely, $9=$ like extremely $)$.

tructured jerky added with glutinous rice flour and potato starch, the crispiness was increased as the amount of soybean powder was decreased because the content of soybean powder, $20.9 \%$ (refer to food composition table), would affect the properties of the restructured jerky. The $5 \%$ added samples showed the highest overall acceptability without significant differences compared to the samples added with $9 \%$ and $13 \%$. In addition to the highest overall acceptability, it was also scored high in appearance, flavor, taste, and texture so that added with $5 \%$ of soybean powder is recommended. The appearance of the samples added with acorn powder was generally less preferred than that of the ones with glutinous rice flour, potato starch, and soybean powder. Significant differences were not showed in the flavor by the content of acorn powder. Only the samples with $15 \%$ of acorn powder were showed significantly low in taste $(p<0.05)$. Although crispiness was increased as the amount of acorn powder was increased like the other additives, there was no significant difference showed in acceptability among the additives. Since significant differences were not showed in texture acceptability but in flavor and taste for the samples with $9 \%$ addition of the additive was suggested to be the optimal addition volume.

\section{Conclusion}

The results of this study showed that the restructured jerky added with glutinous rice flour, potato starch, soybean, and acorn powder was effective to lower moisture content, water activity, as well as TBARS and dry yield. According to sensory evaluations, the highest overall ac- 
ceptability was showed when $9 \%$ of glutinous rice flour, potato starch, and acorn powder was added to the products samples. However, for soybean powder $5 \%$ addition was also present highest overall acceptability. Therefore, it is suggested that the addition of glutinous rice flour, potato starch, soybean, and acorn powder could potentially be as fat replacements, providing the consumer with a new type of jerky.

\section{References}

1. Acton, J. C. and Dick, R. L. (1977) Cured color development during fermented sausages processing. J. Food Sci. 42, 895879.

2. Ali, R. F. M., El-Anany, A. M., and Gaafar, A. M. (2011) Effect of potato flakes as fat replacer on the quality attributes of low-fat beef patties. Adv. J. Food Sci. Technol. 3, 173-180.

3. Allen, K., Cornforth, D., Whittier, D., Vasavada, M., and Nummer, B. (2007) Evaluation on high humidity and wet marinade methods for pasteurization of jerky. J. Food Sci. 72, 351-355.

4. AOAC. (1990) Official Method of Analysis of AOAC Int'1. $15^{\text {th }}$ ed. Method 991.43. Association of Official Analytical Communities, Arlington, VA, USA

5. Banwart, G. J. (1979) Basic food microbiology. AVI Publishing Company Inc., Westport. CT. USA

6. Berry, B. W. (1997) Sodium alginate plus modified tapioca starch improves properties of low-fat beef patties. J. Food Sci. 62, 1245-1249.

7. Calicioglu, M., Sofos, J. N., Samelis, J., Kendall, P. A., and Smith, G. C. (2003) Effect of acid adaption on inactivation of salmonella during drying and storage of beef jerky treated with marinades. Int'l. J. Food Microbiol. 89, 51-65.

8. Carr, M. A., Miller, M. F., Daniel, D. R., Yarbrogh, C. E., Petrosky, J. D., and Thompson, L. D. (1997) Evaluation of the physical, chemical and sensory properties of jerky processed from emu, beef and turkey. J. Food Quality 20, 419-425.

9. Cava, R., Ladero, L., González, S., Carrasco, A., and Ramírez, M. R. (2009) Effect of pressure and holding time on colour, protein and lipid oxidation of sliced dry-cured Iberian ham and loin during refrigerated storage. Innovative Food Sci. Emerging Technol. 10, 76-81.

10. Chasco, J., Lizaso, G., and Beriain, M. J. (1996) Cured colour development during sausage processing. Meat Sci. 44, 203211.

11. Chin, K. B., Keeton, J. T., Longnecker, M. T., and Lamley, J. W. (1999) Utilization of soy protein and konjac blends in low-fat bologna (model system). Meat Sci. 53, 45-57.

12. Choi, Y. I. and An, K. Y. (1996) Effects of phosphate type and addition level on binding ability, microstructure and storage characteristics of restructured pork jerky. Korean J. Anim. Sci. Technol. 38, 159-170.

13. García-Esteban, M., Ansorena, D., and Astiasarán, I. (2004) Comparison of modified atmosphere packaging and vacuum packaging for long period storage of dry-cured ham: Effects on colour, texture and microbiological quality. Meat Sci. 67, 57-63.

14. Han, D. J., Jung, J. Y., Choi, J. H., Choi, Y. S., Kim, H. Y., Lee, M. A., Lee, E. S., Paik, H. D., and Kim, C. J. (2007) Effects of drying conditions on quality properties of pork jerky. Korean J. Food Sci. An. 27, 29-34.

15. Hughes, E., Cofrades, S., and Troy, D. J. (1997) Effect of fat level, oat fiber and carrageenan on frankfurters formulated with 5, 12 and 30\% fat. Meat Sci. 45, 273-281.

16. Im, J. K. (1992) The effect of water activity on quality and storage stability of dried beef jerky. MS Thesis. Korea University, Korea

17. Jin, K. B. and Ban, G. H. (2008) Evaluation of two levels and types of acorn powder on product quality of low-fat sausages as a fat replacer. Korean J. Anim. Sci. Technol. 50, 217-226.

18. Jung, S. W., Baek, Y. S., Kim, Y. S., and Kim, Y. H. (1994) Quality changes of beef jerky during storage. Korean J. Anim. Sci. Technol. 36, 693-697.

19. Kayaardi, S. and Gok, V. (2004) Effect of replacing beef fat with olive oil on quality characteristics of Turkish soudjouk (sucuk). Meat Sci. 66, 249-257.

20. Kim, J. M. and Lee, C. M. (1987). Effect of starch on textural properties of surimi gel. J. Food Sci. 52, 722-725.

21. Kwon, J. H., Kim, S. J. Lee, J. E., Lee, S. J., Kim, S. K., Kim, J. S., and Byun, M. W. (2002) Physicochemical and organoleptic properties of starch isolated from gamma-irradiated acorn. Korean J. Food Sci. Technol. 34, 1007-1012.

22. Lee, H. C. and Jin, K. B. (2004) Reduction of tumbling time and improvement of shear value for the manufacture of restructured hams using transglutaminase. Korean J. Food Sci. An. 24, 21-28

23. Lee, M. H., Jeon, J. H., and Oh, K. J. (1992) Antioxidative activity of garlic acid in acorn extract. J. Korean Soc. Food Sci. Nutr. 21, 693-700.

24. Lee, S. J. and Park, G. S. (2004) The quality characteristics of beef jerky prepared with various spices. Korean J. Food Cookery Sci. 20, 489-497.

25. Lee, S. W. and Kang, C. S. (2001) Effect of moisture content on quality changes of dried ostrich meat. J. Health Sci. Med. Technol. 27, 29-34.

26. Leward, P. (1981) Intermediate moisture meats. Meat Sci. 2 , 159-194.

27. Li, J. Y. and Yeh, A. I. (2003) Effects of starch properties on rheological characteristics of starch/meat complexes. J. Food Eng. 57, 287-294.

28. Lopes, G. K., Schulman, H. M., and Hermes-Lima, M. (1999) Polyphenol tannic acid inhibits hydroxyl radical formation from fenton reaction by complexing ferrous ions. Biochem. Biophy. Acta 1472, 142-152.

29. Mancini, R. A. and Hunt, M. C. (2005) Current research in meat color. Meat Sci, 71, 100-121.

30. Mgbemere, V. N., Akpapunam, M. A., and Igene, J. O. (2011) Effect of groundnut flour sbstitution on yield, quality and storage stability of kilishi Nigerian indigenous dried meat product. Afr. J. Food Agri. Nutr. Develop. 11, 4718-4738. 
31. Munoz, I. Garcia-Gil, N. Arnau, J., and Gou, P. (2012) Rehydration kinetics at 5 and $15^{\circ} \mathrm{C}$ of dry salted meat. J. Food Eng. 110, $465-471$.

32. Oh, J. S. (2004) Quality characteristics of beef jerky prepared with different methods. MS thesis, Sunchon Univ., Sunchon, Korea.

33. Park, C. J. Kim, M. L., and Park C. S. (2009) Effects of drying method and medicinal extract addition on the microstructure of beef jerky. Korean J. Food Preserv. 16, 875-883.

34. Park, G. Y., Hong, C. K., Cho, S. A., Choi, Y. H., Shin, Y., Han, S. U., and Chough, N. J. (2005) Evaluation of the quality on confectionary. J. Food Hyg. Safety 20, 179-184.

35. Park, K. S., Choi, Y. J., Moon, Y. H., Park, H. S., Kim, M. J., and Jung, I. C. (2012) Physicochemical characteristics of ground pork with safflower seed powder as an animal fat replacer. J. Life Sci. 22, 928-935.

36. Pearson, A. M. and Gillett, T. A. (1999) Effects of fat on flavor in processed meats. $3^{\text {rd }}$ Ed., Aspen publication, Aspen Publisher, Inc. Gaithersburg, Maryland, pp: 356-358.

37. Raharjo, M. C. and Brewer, M. S. (2007) Effect of natural antioxidants on oxidative stability of cooked, refrigerated beef and pork. J. Food Sci. 72, S282-S288.

38. Rubio, B., Martínez, B., García-Cachán, M. D., Rovira, J., and Jaime, I. (2008) Effect of the packaging method and the storage time on lipid oxidation and colour stability on dry fermented sausage salchichón manufactured with raw material with a high level of mono and polyunsaturated fatty acids. Meat Sci. 80, 1182-1187.

39. SAS (2008) SAS/STAT Software for PC. Release 9.2, SAS Institute Inc., Cary, NC, USA.

40. Shewry, P. R. and Tatham, A. S. (2000) Wheat gluten. Special publication. Royal Soc. Chem. 261, 500-548.

41. Skrede, G. (1989). Comparison of various types of starch when used in meat sausages. Meat Sci. 25, 21-36.
42. Torres, E. A. S., Shimokomaki, M., Franco, B. D. G. M., Landgraf, M., Carvalho, B. C., and Santos, J. C. (1994) Quality parameters determination of charqui, an intermediate moisture meat product. Meat Sci. 38, 229-234.

43. Torres, E. A. F. S., Shimok omaki, M., Franco, B. O. G. M., and Landgarf, M. (1994) Parameters determining the quality of charqui, an intermediate moisture meat product. Meat Sci. 38, 229.

44. Trout, E. S., Hunt, M. C., Johnson, D. E., Claus, J. R., Kastner, C. L., and Kropf, D. H. (1992). Characteristics in low-fat ground beef containing texture modifying ingredients. J. Food Sci. 57, 19-24.

45. Van Laak, R. L. J. M. (1994) Spoilage and preservation of muscle foods. In: Muscle foods. Kinsman. M., Kotula, A. W. and Breidenstein, B. C. (eds) Chapman \& Hall, Inc., NY. pp. 378-405.

46. Verrez-Bagnis, V., Bouchet, B., and Gallant, D. J. (1993). Relationship between the starch granule structure and the textural properties of heat-induced surimi gel. Food Structure 12, 309-320.

47. Witte, V. G., Krause, G. F., and Bailey, M. E. (1970) A new extraction method for determining 2-thiobarbituric acid value of pork and beef during storage. J. Food Sci. 35, 582-585.

48. Wu, M. C., Lanier, T. C., and Hamann, D. D. (1985). Thermal transitions of admixed starch/fish protein systems during heating. J. Food Sci. 50, 20-25.

49. Yang, H. S., Hwang, Y. H., Joo, S. T., and Park, G. B. (2009) The Physicochemocal and microbiological characteristics of pork jerky on comparison to beef jerky. Meat Sci. 82, 289294.

50. Yildiz-Turp, G. and Serdaroglu, M. (2008) Effect of replacing beef fat with hazelnut oil on quality characteristics of sucuk-A Turkish fermented sausage. Meat Sci. 78, 447-454.

$\overline{\text { (Received 2013.5.28/Revised 2013.8.29/Accepted 2013.8.30) }}$ 